Humanistika: Jurnal Keislaman

Vol. 7 No. 2 2021. ISSN (Print): 2460-5417 ISSN (Online): 2548-4400

DOI: https://doi.org/10.36835/humanistika.v7i2.609

\title{
PERANAN ORANGTUA MURTAD TERHADAP PEMELIHARAAN ANAK
}

(Studi Perbandingan Antara Kompilasi Hukum Islam Dengan

Undang-Undang Perlindungan Anak)

\author{
Achmad Roni \\ Universitas Wijaya Kusuma Surabaya \\ roniadot@gmail.com
}

\section{ABSTRACT}

Child care in Islam was known as Hadlanah which is an activity to taking care the children until they reach adulthood, child care becomes a problem when their parents apostatize, because there are two different legal products that regulate child care for apostate parents, namely the Compilation of Islamic Law and Child Protection Act. The compilation of Islamic Law requires that people who have the rights to care for children, including parents, should be Muslims. Meanwhile, the Child Protection Law doesn't require any religion to be able to care for children. This study use a normative legal research method with a descriptive approach. The results are found in the legal system of the Indonesian State, the composition of legal norms and rules are contained in the hierarchy of the Law on the Formation of Legislation, the Compilation of Islamic Law is not contained in it because it is a product of Indonesian Figh which is the development and renewal of Islamic Law for the Indonesian people, especially in the Court. Religion is in accordance with the recommendation of the Minister of Religion who carries out the orders of the Presidential Instruction. So for parents who are apostate, the legal basis used is the Child Protection Law and they are still obliged to look after the

https://ejournal.unzah.ac.id/index.php/humanistika 
Achmad Roni

children because there is no religious requirement in the Child Protection Law.

Keywords: Apostate parent, child care, child protection law.

Humanistika: Vol.7 No.2 2021 
Peranan Orangtua Murtad Terhadap Pemeliharaan Anak

Humanistika: Vol.7 No.2 2021 


\section{ABSTRAK}

Pemeliharaan anak dalam Islam dikenal dengan istilah Hadlanah yang merupakan kegiatan merawat dan menumbuhkembangkan anak hingga mencapai usia dewasa, pemeliharaan anak menjadi persoalan ketika orangtua anak murtad, karena ada dua produk hukum yang berbeda ketentuan mengatur terkait pemeliharaan anak bagi orangtua murtad yaitu Kompilasi Hukum Islam dan Undang-Undang Perlindungan Anak. Kompilasi Hukum Islam mensyaratkan orang yang berhak melakukan pemeliharaan anak termasuk orangtua adalah yang beragama Islam. Sedangkan Undang-Undang Perlindungan anak tidak mensyaratkan adanya agama tertentu untuk dapat melakukan pemeliharaan anak. Penelitian ini menggunakan metode penelitian hukum normatif dengan pendekatan deskriptif. Hasilnya didapati dalam sistem hukum Negara Indonesia, susunan norma hukum aturannya terdapat dalam hirarki Undang-Undang Pembentukan Peraturan Perundang-undangan, Kompilasi Hukum Islam tidak terdapat di dalamnya karena merupakan suatu produk fiqh Indonesia yang sifatnya pengembangan dan pembaharuan Hukum Islam untuk masyarakat Indonesia khususnya di Pengadilan Agama sesuai anjuran Menteri Agama yang melaksanakan perintah Instruksi Presiden. Sehingga bagi orangtua yang murtad dasar hukum yang digunakan adalah Undang-Undang Perlindungan anak dan tetap berkewajiban memelihara anak karena tidak ada syarat agama dalam UndangUndang Perlindungan anak.

Kata Kunci: Orangtua murtad; Pemeliharaan Anak; UndangUndang Perlindungan Anak.

Humanistika: Vol.7 No.2 2021 


\section{Peranan Orangtua Murtad Terhadap Pemeliharaan Anak}

\section{Pendahuluan}

Orangtua memiliki kewajiban untuk memelihara dan mengasuh anaknya sampai anak tersebut mencapai usia dewasa. Kegiatan mengasuh dan memelihara anak atau Hadlanah merupakan kegiatan merawat dan menumbungkembangkan anak hingga mencapai usia dewasa. ${ }^{1}$ Meskipun pada hari ke depan telah terjadi perceraian, anak masih menjadi tanggung jawab orangtua. Kewajiban tersebut sesuai ketentuan dalam Pasal 26 Undang-Undang Nomor 25 Tahun 2014 Perubahan atas Undang-Undang Nomor 23 Tahun 2002 tentang Perlindungan Anak (UU Perlindungan Anak) yang menyatakan "Orangtua memiliki kewajiban untuk mengasub, merawat memelihara, mendidik dan melindungi anak. Menumbubkembangkan bakat dan minat anak dan mencegah terjadinya perkawinan usia dini. Apabila orangtua anak meninggal dunia atau karena suatu sebab tertentu tidak dapat menjalankan kewajiban dan tanggungjawabnya sebagai orangtua kepada anaknya, kewajiban itu dapat dialibkan kepada keluarga".

Mengedepankan perlindungan anak menjadi hal yang paling utama dalam keluarga supaya anak bisa tumbuh, berkembang secara baik dan sehat. Kepentingan terbaik anak merupakan asas dalam perlindungan anak yang paling ditekankan dalam pemeliharaan anak. Penjelasan dalam asas tersebut adalah berbagai macam perilaku dan tindakan yang berhubungan dengan anak harus mengedepankan kepentingan yang paling terbaik bagi kehidupan anak ${ }^{3}$ Namun, yang menjadi persoalan dalam pemeliharaan anak adalah ketika orangtua anak

${ }^{1}$ Ketentuan Umum Pasal 1 huruf g Inpres No. 1 Tahun 1999 tentang Kompilasi Hukum Islam.

${ }^{2}$ Pasal 26 Undang-Undang Perlindungan Anak.

${ }^{3}$ Pasal 2 dan Penjelasannya Undang-Undang Perlindungan Anak.

Humanistika: Vol.7 No.2 2021 


\section{Achmad Roni}

murtad (pindah agama dari agama Islam ke agama lain). Menurut Kompilasi Hukum Islam (KHI) menjelaskan bahwa syarat untuk hadlanah adalah bisa merawat anak tersebut secara jasmani dan rohani yang terdapat dalam Pasal $77 \mathrm{KHI}^{4}$ dan menurut ulama fiqih syarat untuk menjalakan hadlanah adalah:

1. Baligh;

2. Berakal;

3. Mampu merawat;

4. Islam;

5. Merdeka. ${ }^{5}$

Penjelasannya, di dalam syarat-syarat hadlanah ada syarat beragama Islam untuk dapat memelihara anak. Apabila orangtua anak murtad maka, orangtua tersebut tidak bisa memelihara anak karena tidak memenuhi syarat hadlanah dan keluarga anak dapat mengajukan hak asuh pemeliharaan anak tersebut.

Ketentuan pemeliharaan anak menurut KHI seperti yang sudah dijelaskan di atas berbeda dengan ketentuan UU Perlindungan Anak. UU Perlindungan Anak menjelaskan bahwa orangtua mempunyai kewajiban memelihara dan menumbuhkembangkan anak sampai anak tersebut mencapai usia dewasa. Tidak ada ketentuan syarat agama tertuntu bagi orangtua supaya bisa memelihara anaknya sehingga, orangtua tetap memiliki kewajiban mengasuh, merawat dan memelihara anaknya sampai anak mencapai usia dewasa.

Dalam persoalan pemeliharaan anak terhadap orangtua murtad peneliti mendapatkan dua produk hukum yang berbeda pandangan hukumnya. Pertama, produk hukum KHI yang mensyaratkan pemeliharaan anak harus beragama Islam termasuk juga bagi orangtua

\footnotetext{
${ }^{4}$ Pasal 77 Kompilasi Hukum Islam.

5 Al-Imam Abu Zakaria Muhyiddin ibn Syarif al-Nawawi. al-Majmu'Syarh alMazhab. Dar al-Fikr, terjemah-18, h. 320.

Humanistika: Vol.7 No.2 2021
} 


\section{Peranan Orangtua Murtad Terhadap Pemeliharaan Anak}

anak. Kedua, UU Perlindungan Anak yang berpandangan bahwa orangtua wajib memelihara anaknya sampai anak tersebut mencapai usia dewasa. Sementara dalam hirarki perundang-undangan di Indonesia KHI tidak masuk di dalamnya karena bukan termasuk Undang-Undang.

Peneliti merasa tertarik untuk melakukan pembahasan mengenai peranan orangtua murtad terhadap pemeliharaan anak. Karena terdapat dua produk hukum yang mengatur tentang pemeliharaan anak yang saling bertentangan yaitu KHI dengan UU Perlindungan Anak dan juga mengenai legalitas KHI dalam peraturan perundangundangan.

\section{Metode Penelitian}

Jenis penelitian yang digunakan untuk menganalisa dalam penelitian ini menggunakan penelitian hukum normatif yaitu penelitian hukum yang mengkaji hukum tertulis yang dilihat dari beberapa aspek seperti teori, sejarah, dan perbandingan hukum. Tipe penelitian ini menggunakan penelitian deskriptif untuk memperoleh pemaparan secara lengkap tentang aspek yang diteliti dalam suatu peraturan perundang-undangan. Tipe pendekatan yang digunakan untuk penelitian ini menggunakan perbandingan hukum antara KHI dengan UU Perlindungan Anak

\section{Pembahasan}

\section{Hirarki Perundang-undangan di Indonesia}

Indonesia sebagaimana negara hukum yang tercantum dalam Konstitusi Undang-Undang Dasar 1945 mempunyai konsekuensi segala aspek kehidupan dalam bidang kemasyarakatan dan

Humanistika: Vol.7 No.2 2021 


\section{Achmad Roni}

pemerintahan Indonesia harus berdasarkan atas hukum yang salah satunya terwujud dalam berbagai peraturan negara.

Sistem hukum tersebut disusun secara berjenjang dan bertingkattingkat seperti anak tangga. Hal itu diperlukan supaya hukum tidak saling bertentangan antara satu sama lain. Hubungan antara norma satu dengan yang lainnya disebut hubungan super dan sub-ordinasi dalam konteks spasial. ${ }^{6}$

Di negara Indonesia, susunan norma hukum ini diaktualisasikan ke dalam hierarki peraturan perundang-undangan sebagaimana tercantum dalam Undang-Undang Nomor 15 Tahun 2019 tentang Perubahan atas Undang-Undang Nomor 12 Tahun 2011 tentang Pembentukan Peraturan Perundang-undangan. Secara legal historis hierarki peraturan perundang-undangan di Indonesia telah mengalami 4 (empat) kali perubahan yaitu melalui Tap MPRS No. XX/MPRS/1966, Tap MPR Nomor III/MPR/2000, UU No. 10 Tahun 2004, dan UU No. 12 Tahun 2011.7

Peraturan Perundang-undangan sendiri mempunyai definisi yaitu peraturan yang tertulis memuat norma hukum yang mengikat bagi masyarakat secara umum. Peraturan Perundang-undangan disusun, dibentuk kemudian ditetapkan oleh lembaga negara melalui prosedur sesuai dengan Peraturan Perundang-undangan. Pasal 7 ayat (1) UU Pembentukan Peraturan Perundang-undangan menyatakan mengenai jenis dan hierarki peraturan perundang-undangan yang ada di Indonesia, antara lain:

${ }^{6}$ Jimly Asshiddiqie dan M. Ali Safa'at. (2006). Theory Hans Kelsen Tentang Hukum. Cetakan 1. Jakarta: Sekretariat Jenderal dan Kepaniteraan Mahkamah Konstitusi RI, h. 110.

7 Artikel Jurnal: Zaka Firma Aditya dan M. Reza Winata. (2018) "Rekonstruksi Hierarki Peraturan Perundang-Undangan Di Indonesia" Negara Hukum, Vol. 9, No. 1, h. 19.

Humanistika: Vol.7 No.2 2021 


\section{Peranan Orangtua Murtad Terhadap Pemeliharaan Anak}

1. Undang-Undang Dasar Negara Republik Indonesia Tahun 1945;

2. Ketetapan Majelis Permusyawaran Rakyat;

3. Undang-Undang/Peraturan Pemerintah Pengganti UndangUndang;

4. Peraturan Pemerintah;

5. Peraturan Presiden;

6. Peraturan Daerah Provinsi;

7. Peraturan Daerah Kabupaten/Kota.

Penjelasan dari pasal tersebut adalah kekuatan hukum dari peraturan perundang-undangan berurutan sesuai dengan hirarki yang disebutkan di atas. Artinya adalah Undang-Undang Dasar Negara Republik Indonesia Tahun 1945 merupakan konstitusi sebagai norma dasar Negara Indonesia. Norma dasar ini mengakibatkan konsekuensi yang harus dijalani. Pertama, acuan dari semua peraturan perundangundangan sebagaimana dikenal dengan asas dari lex superiori derogat legi inferiori. Kedua, materi muatan dari Undang-Undang Dasar Tahun 1945 menjadi acuan dalam segala macam pembentukan peraturan perundang-undangan yang akan dibentuk, sehingga Ketetapan MPR hingga Peraturan Daerah Kabupaten/Kota harus menyesuaikan dengan UUD Tahun 1945 dan tidak boleh bertentangan. Apabila peraturan perundang-undangan yang lebih rendah bertentangan dengan peraturan di atasnya, maka dapat diajuikan untuk dituntut dibatalkan (van rechtswegenietig). ${ }^{8}$

Materi muatan di setiap produk hukum yang dikeluarkan harus memperhatikan hierarki perudang-undangan, karena setiap peraturan

8 Artikel Jurnal: Ni'matul Huda. (2006). "Kedudukan Peraturan Daerah dalam Hierarki Peraturan Perundang-Undangan”. Ius Quia Iustum, Vol. 13 No. 1, h. 29.

Humanistika: Vol.7 No.2 2021 


\section{Achmad Roni}

perundang-undangan itu mengatur suatu materi atau hal keadaan/ konkret. ${ }^{9}$

\section{Kompilasi Hukum Islam dalam Hirarki Perundang-Undangan di Indonesia}

Kompilasi Hukum Islam (KHI) merupakan salah satu aspek hukum yang diambil dari hukum Islam yang ada di Indonesia. Hukum Islam menjadi hal yang paling penting di dalam kehidupan masyarakat Indonesia pada masa sekarang. Secara garis besar KHI terdiri dari tiga buku, pertama tentang Perkawinan (Munakahat), kedua tentang Kewarisan (Faraid), dan ketiga tentang Perwakafan. Dalam kerangka sistematika KHI terbagi dalam beberapa bab yang selanjutnya dirinci di dalam pasal-pasal. ${ }^{10}$

Legalitas keberadaan KHI di Indonesia terdapat pada Instruksi Presiden No. 1 Tahun 1991 tanggal 10 Juni 1991. Pada waktu itu oleh karena dalam bidang perkawinan, kewarisan dan perwakafan telah ditetapkan oleh undang-undang yang berlaku menjadi hukum Islam, maka hukum Islam yang memuat hukum materilnya kemudian ditetapkan oleh Keputusan Presiden dengan Instruksi Presiden. Selanjutnya Instruksi Presiden tersebut dasar hukumnya adalah pada Pasal 4 ayat (1) Undang-Undang Dasar 1945, yaitu kekuasaan Presiden untuk memegang kekuasaan pemerintahan negara. Oleh karena itu, kedudukan KHI tidak terlepas dari Instruksi Presiden. ${ }^{11}$

9 Artikel Jurnal: Bayu Dwi Anggono. (2018). "Tertib Jenis, Hierarki, dan Materi Muatan Peraturan Perundang-Undangan: Permasalahan dan Solusinya". MasalahMasalah Hukum, Jilid 47 No. 1, h. 6.

${ }^{10}$ Kompilasi Hukum Islam.

11 Artikel Jurnal: Edy Gunawan. (2016). "Eksistensi Kompilasi Hukum Islam di Indonesia”, Jurnal Ilmiah Al-Syir'ah, Vol VIII, No. 1, h. 8.

Humanistika: Vol.7 No.2 2021 


\section{Peranan Orangtua Murtad Terhadap Pemeliharaan Anak}

Instruksi Presiden mengenai KHI ditujukan kepada Menteri Agama supaya Menteri Agama dapat menyebarluaskan KHI yang sudah ditetapkan oleh Presiden tersebut. Kemudian landasan KHI selanjutnya adalah berdasarkan Keputusan Menteri Agama Republik Indonesia tanggal 22 Juli 1991 No. 154 Tahun 1991 tentang Pelaksana Instruksi Presiden Republik Indonesia No. 1 Tahun 1991. Keputusan ini menyatakan:

1. Babwa Instruksi Presiden Indonesia No. 1 Tabun 1991 tanggal 10 Juni 1991 memerintabkan kepada Menteri Agama untuk menyebarluaskan Kompilasi Hukum Islam untuk digunakan oleh Instansi Pemerintah dan masyarakat yang memerlukannya;

2. Babwa penyebarluasan Kompilasi Hukum Islam tersebut perlu dilaksanakan dengan sebaik-baiknya dan dengan penub tanggung jawab;

3. Babwa oleb karena itu, perlu dikeluarkan Keputusan Menteri Agama Republik Indonesia tentang pelaksanaan Instruksi Presiden Republik Indonesia Nomor 1 Tabun 1991 tanggal 10 Juni 1991. ${ }^{12}$

Pengaturan lebih lanjut mengenai KHI terdapat dalam Surat Edaran Direktur Pembinaan Badan Peradilan Islam atas nama Direktur Jenderal Pembinaan Kelembagaan Agama Islam tanggal 25 Juli 1991 No. 3694/EV/HK.003/AZ/91 yang ditujukan kepada Ketua Pengadilan Tinggi Agama dan Ketua Pengadilan Agama di seluruh Indonesia yang isinya adalah tentang penyebarluasan Instruksi Presiden RI No. 1 Tahun 1991 tanggal 10 Juni 1991.

Jika ditinjau dari ilmu hukum dan dari norma hukum, instruksi selalu bersifat individual konkret. Maksudnya adalah perintah dari pemberi instruksi dan penerima instruksi hanya berlaku bagi yang berhubungan organisasi secara langsung. Hal ini tentu berbeda dengan

12 ibid., h. 10.

Humanistika: Vol.7 No.2 2021 


\section{Achmad Roni}

Undang-Undang dan Peraturan Pemerintah. Maka, dengan demikian Inpres No. 1 tahun 1991 itu karena ditujukan dari Presiden kepada Menteri Agama Republik Indonesia bersifat individual konkret, Karena intruksinya berhubungan dengan jabatan dalam suatu organisasi. ${ }^{13}$

Penjelasan lebih lanjut, KHI ini merupakan suatu produk dari fiqih Indonesia yang bernuansa untuk pengembangan dan pembaharuan Hukum Islam masyarakat di Negara Indonesia khususnya di Pengadilan Agama. Ternyata, dalam perjalanan KHI dalam mengarungi kehidupan masyarakat Indonesia membuat para akaemisi Hukum Islam Indonesia tertarik, Hal ini dikarenakan KHI tidak terdapat dalam tata urutan hierarki UU No. 12 Tahun 2011. Kekuatan keberlakukan hukum yang terhadap hierarki peraturan perundang-undangan dinyatakan pada Pasal 7 ayat (2) yang berbunyi: "Kekuatan bukum Peraturan Perundang-undangan sesuai dengan bierarki sebagaimana dimaksud pada ayat (1)".

Selanjutnya, atas anjuran dari Menteri Agama melaksanakan Instruksi Presiden Kompilasi Hukum Islam diberlakukan di semua Pengadilan Agama di Indonesia. Dari sejarah perjalanan pengesahan KHI kekuatan hukum dari KHI jika ditinjau dari tatanan hukum Peraturan Perundang-undangan Indonesia, kekuatan hukum KHI sama sekali tidak ada. Karena KHI berasal dari inpres yang dalam hirerarki hukum yang berlaku bukanlah kewajiban yang musti dijalankan karena bukan aturan hukum. KHI dalam Inpres merupakan anjuran atau petunjuk dari Presiden kepada Menteri Agama.

13 Zainuddin Ali. (2006). Hukum Islam Pengantar Ilmu Hukum Islam di Indonesia. Cet. Ke-1. Jakarta: Sinar Grafika, h. 153.

Humanistika: Vol.7 No.2 2021 


\section{Peranan Orangtua Murtad Terhadap Pemeliharaan Anak}

Bentuk kekuatan hukum dari KHI berdasarkan tatanan hukum Indonesia dilihat dari yuridis-formal hakim Pengadilan Agama boleh menjalankan dan boleh juga tidak. Sedangkan jika dilihat dari yuridis nonformal kehadiran KHI ini merupakan hukum-hukum yang hidup di dalam masyarakat muslim di Indonesia, yang dikumpulkan dalam bentuk "kompilasi". Bagir Manan yang merupakan mantan Mahkamah Agung Republik Indonesia berpendapat bahwa "Instruksi Presiden" tidak tergolong peraturan perundang-undangan. Instruksi Presiden berisi ketentuan konkrit yang harus dilaksanakan atau tidak dilakukan pejabat administrasi negara. ${ }^{14}$

Dengan demikian KHI tidak ada di dalam hierarki perundangundangan berdasarkan UU Pembentukan Peraturan Perundangundangan. KHI merupakan kumpulan hukum yang dihimpun dari hukum-hukum yang hidup di masyarakat.

\section{Pemeliharaan Anak Menurut Khi Dan Uu Perlindungan Anak Pemeliharaan Anak Menurut KHI}

Pasal di dalam KHI yang mengatur soal pemeliharaan anak terdapat pada pasal 77 ayat (3) yang berbunyi: "Suami isteri memikul kewajiban untuk mengasub dan memelihara anak-anak mereka, baik mengenai pertumbuban jasmani, rohani maupun kecerdasannya dan pendidikan agamanya"

Kompilasi Hukum Islam berpatokan pada ajaran-ajaran dari agama Islam. Pemeliharaan anak menurut Islam disebut hadlanah. Pengertian secara istilah adalah kegiatan merawat anak, mendidik, dan

14 Artikel Jurnal: Asril. (2015). "Eksistensi Kompilasi Hukum Islam Menurut Undang-Undang Nomor 12 Tahun 2011 tentang Pembentukan Peraturan PerundangUndangan”. Hukum Islam, Vol XV No. 1, h. 38-39.

Humanistika: Vol.7 No.2 2021 


\section{Achmad Roni}

menjaga anak hingga mencapai usia dewasa oleh orang yang memiliki tanggung jawab misalnya, orangtua. Menurut Zainuddin kegiatan ini diperlukan karena anak mash belum mengetahui apa saja hal-hal yang akan menciderainya karena tiadanya kemampuan memilah. ${ }^{15}$

Kalangan perempuan lebih berhak untuk menjalankan hadlanah ketimbang laki-laki. Sebagaimana telah disepakati oleh jumhur ulama. Menurut pertimbangan jumhur ulama kenapa harus perempuan, karena mereka lebih unggul dalam hal belas kasih, ketelatenan merawat, kesabaran dan lebih intens menjaganya, hanya saja masingmasing berbeda-beda menentukan urutan-urutan siapa yang lebih utama. Selanjutnya, Syarat-Syarat Menjalankan Hadlanah sebagai berikut:

1. Baligh

2. Berakal:

Hanabilah menambahkan syarat selain berakal yatu sehat dan tidak berpenyakit.

3. Mampu merawat

Pemegang hadlanah harus dapat memelihara akhlak dan kesehatan badan si anak. Orang yang sibuk dalam urusan lain tidak berhak hadlanah.

4. Akhlak terpercaya.

Orang yang tidak bisa dipercaya merawat dan membina akhlak anak ditinjau dari sifatnya dan perilakunya tidak berhak memegang hak hadlanah, contohnya, pemabuk, pezina atau perbuatan haram lainnya.

5. Islam

6. Merdeka

15 Zainuddin ibn Abd al-Aziz al-Malibẫri al-Fanẫni. (1418 H/ 1997 M). Fath al-Mu'ĩn li al-Syarh Qurrat al- 'Aini. Cet. 1. Beirut Libanon, j-4, h. 115.

Humanistika: Vol.7 No.2 2021 


\section{Peranan Orangtua Murtad Terhadap Pemeliharaan Anak}

Orang yang tidak merdeka tidak boleh diberikan hak Hadlanah karena ia tidak akan sanggup melaksanakan sambil mengabdi kepada tuannya. ${ }^{16}$

Mengenai terjadinya perceraian dan persoalan pemeliharaan anak KHI mengaturnya dalam Pasal 105 yang berbunyi:

"Dalam hal terjadinya perceraian:

a. Pemeliharaan anak yang belum mumayyiz, atau belum berumur 12 tabun adalah hak ibunya;

b. Pemeliharaan anak yang sudah mumayyiz diserabkan kepada anak untuk memilib di antara ayah atau ibunya sebagai pemegang hak pemelibaraanya;

c. Biaya pemeliharaan ditanggung oleh Ayabnya"

Penjelasan lebih lanjut terkait Pasal 105 KHI jika perceraian telah terjadi, Jika anak itu sudah mumayyiz, ketentuannya adalah bahwa hak asuh itu kembali pada prinsip bahwa peiaksanaan hak asuh ini dasarnya adalah kepentingan atau kemaslahatan anak, maka anak yang sudah mumayyiz diberi kebebasan menentukan piiihan tentang hak asuhnya

kepada ibu atau bapak. ${ }^{17}$ Jika anak masih mumayyiz maka pemeliharaan anak menjadi hak ibunya jika anak masih belum dewasa atau anak belum tamyiz. kecuali ibunya telah meninggal dunia, maka pemeliharaan anak dapat dialihkan kepada keluarga yang lain. ${ }^{18}$

Apabila keduanya sama-sama memenuhi persyaratan untuk menjadi hadbun (pemelihara anak) maka ia berhak atas anaknya, bila

16 Al-Imam Abu Zakaria Muhyiddin ibn Syarif al-Nawawi. al-Majmu'Syarh alMazhab. Dar al-Fikr, terjemah-18, h. 320.

17 Artikel Jurnal: Rohidin. (2005). "Pemeliharaan Anak Dalam Perspektif Fiqh dan Hukum Positif” Jurnal Hukum, No. 29 Vol. 2, 88-98.

18 Artikel Jurnal: Aris Bintania. (2011). "Hak Asuh (Hadlanah) Isteri Murtad Menurut Hukum Positif dan Hukum Islam.” Toleransi, Vol 3 No.1, 2011. h. 12-13.

Humanistika: Vol.7 No.2 2021 


\section{Achmad Roni}

anaknya masih mumayyiz (di bawah umur) maka ibulah yang lebih berhak, karna ibu dianggap lebih dekat dengan anaknya, akan tetapi apabila ayahnya lebih dekat dengan anaknya, maka anak itu tinggal bersama ayahnya. ${ }^{19}$

Jika orangtua kandung tidak bisa atau tidak memenuhi persyaratan, maka pihak keluarga dari ibu atau pihak keluarga dari ayah dengan memenuhi persyaratan-persyaratan yang telah ditentukan.

Mengenai pemeliharaan anak apabila orangtua tidak mampu KHI mengaturnya pada Pasal 98 ayat (3) yang berbunyi: "Pengadilan Agama dapat menunjuk salah seorang kerabat terdekat yang mampu menunaikean kewajiban trsebut apabila kedua orangtuanya tidak mampu"

Dalam Pasal 98 ayat (3) tersebut dengan tegas KHI telah menyatakan jika pemegang hadlanah tidak mampu menjamin tumbuh kembang anak dalam kegiatan pemeliharaan anak, maka Pengadilan Agama atas permohonan keluarga dari anak dapat memindahkan hak hadlanah kepada keluarga yang lain yang mempunyai hak. Hadlanah Sesuai dengan syarat yang ditetapkan ulama fiqh tentang syarat agama Islam, maka jika memang orangtua tidak beragama Islam keluarga lain dpat mengajukan hak hadlanah ke Pengadilan Agama.

\section{Pemeliharaan Anak Menurut UU Perlindungan Anak}

Memelihara kelangsungan hidup anak merupakan kewajiban dan tanggung jawab orangtua sebagaimana Pasal 45 Undang-Undang Nomor 1 Tahun 1974 tentang Perkawinan. Kewajiban ini lebih lanjut dijabarkan dalam Pasal 26 ayat (1) Undang-Undang Nomor 35 Tahun

19 Artikel Jurnal: Aldi Jaya Mandala Putra. (2019). “Tinjauan Yuridis Terhadap Pemeliharaan Anak Dibawah Umur Akibat Suatu Perceraian Berdasarkan Kompilasi Hukum Islam”. Journal Of Law, Vol. 1 No. 1, h. 6.

Humanistika: Vol.7 No.2 2021 


\section{Peranan Orangtua Murtad Terhadap Pemeliharaan Anak}

2014 Perubahan atas Undang-Undang Nomor 23 Tahun 2002 tentang Perlindungan Anak (UU Perlindungan Anak) yang berbunyi:

"Orangtua berkewajiban dan bertanggung jawab untuk:

a. mengasuh, memelihara, mendidik, dan melindungi Anak;

b. menumbubkembangkan Anak sesuai

c. dengan kemampuan, bakat, dan minatnya;

d. mencegah terjadinya perkawinan pada usia Anak; dan

e. memberikan pendidikan karakter dan penanaman nilai budi pekerti pada Anak."

Orangtua sebagai bagian dari lima pilar perlindungan anak yakni orangtua, keluarga, masyarakat, pemerintah, pemerintah daerah dan negara. Kelimanya memiliki keterkaitan satu sama lain sebagai penyelenggara perlindungan anak. Perlindungan anak bersifat melengkapi hak-hak lainnya menjamin bahwa anak-anak akan menerima yang mereka butuhkan agar anak dapat bertahan hidup, berkembang dan tumbuh. ${ }^{20}$

Orangtua memang memiliki andil yang lebih besar dalam melindungi anak karena mereka adalah bagian dari keluarga inti sehingga setiap kebutuhan anak baik jasmani atau rohani haruslah mereka cukupi, namun masyarakat juga turut berperan serta dalam melindungi hak anak. Peran serta masyarakat dapat diwujudkan dengan tetap menjaga hak-hak anak ketika mereka berada diluar

${ }^{20}$ Artikel Jurnal: Amrunsyah. (2017). "Tindak Pidana Perlindungan Anak (Perspektif Hukum Tentang Undang-Undang Perlindungan Anak)" AL-QADHA Jurnal Hukum Islam Dan Perundang-undangan, Vol. 4, No. 1, h. 4.

Humanistika: Vol.7 No.2 2021 


\section{Achmad Roni}

lingkungan rumah sehingga mereka tetap akan merasa nyaman berada diluar rumah. ${ }^{21}$

Orangtua mempunyai kewajiban untuk memelihara anak sampai anak mencapai usia dewasa sepanjang kekuasaan mereka tidak dicabut melalui putusan pengadilan. Ketika terjadi perceraian pada orangtua dari anak, tidak menjadikan kewajiban pemeliharaan anak tersebut menjadi hilang. Tidak ada kategori syarat agama dalam pemeliharaan anak dalam UU Perlindungan anak sebagaimana dijelaskan di atas. Karena pada dasarnya hak anak adalah mendapatkan bimbingan dari orangtuanya.

Apabila terjadi perselisihan terkat hak asuh anak dalam perlindungan anak sesuai dengan makna dan rumusan UndangUndang, bahwa untuk menentukan hak perwalian, yang menjadi pertimbangan penting adalah kepentingan hukum bagi anaknya. Jika terjadi perselisihan hak asuh anak, hakim di Pengadilan harus benarbenar mempertimbangkan apabila anak tersebut diasuh oleh ibunya atau oleh bapaknya dapat menjamin tumbuhkembang anak baik dari segi kehidupan sosial, jasmani dan rohani. Hal yang terpenting adalah kemampuan orangtua untuk merawat, mengasuh danmengarahkan anak untuk dapat baik dalam masa tumbuh kembangnya. ${ }^{22}$

Dengan demikian, jika terjadi perselisihan hak asuh pada anak baik persoalan perceraian kedua orangtua ataupun perselisihan orangtua murtad yang menjadi pertimbangan adalah adalah anak dapat terdukung pertumbuhan yang positif. Pertimbangan ini adalah asas di dalam UU Perlindungan anak dan juga digunakan oleh hakim

21 Artike Jurnal: Rini Fitriani. (2016). "Peranan Penyelenggara Perlindungan Anak Dalam melindungi dan Memenuhi Hak-Hak Anak" Samudtra Keadilan, Vo. 11, No. 2, h. 255.

${ }^{22}$ Artikel Jurnal: Maswandi. (2017). "Hak Asuh Anak Yang Belum Dewasa Setelah Perceraian”, Jurnal Ilmu Pemerintahan dan Sosial Politik, Vol. 5, No. 1, h. 26.

Humanistika: Vol.7 No.2 2021 


\section{Peranan Orangtua Murtad Terhadap Pemeliharaan Anak}

Pengadilan Agama Bangkalan dalam Putusan No. 1284/Pdt.G/2014/PA.Bkl yang mengadili perkara tentang hak asuh anak yang orangtuanya murtad (ibu). Dalam pertimbangan putusannya Hakim memutuskan hak asuh anak diberikan kepada ibu nya. Padahal ibu dalam kasus ini telah telah murtad. Hal ini menjadi pedoman bahwa Hakim lebih mempertimbangkan kepentingan anak yang masih membutuhkan orangtua (ibu). ${ }^{23}$

\section{Kesimpulan}

KHI diambil dari Hukum Islam yang menjadi panduan hidup masyarakat Indonesia yang lalu dikumpulkan dan dibukukan dalam bentuk "kompilasi" selanjutnya ditetapkan melalui Instruksi Presiden Indonesia No. 1 Tahun 1991 dan ditindaklanjuti oleh Menteri Agama untuk diberlakukan di di Pengadilan Agama berdasarkan instruksi Presiden. KHI tidak terdapat dalam tatanan hukum Peraturan Perundang-undangan Indonesia karensa sifatnya berbentuk anjuran atau peunjuk dan bukan hukum yang harus atau wajib dijalankan.

Berdasarkan KHI jika terjadi perceraian, hak pemeliharaan terhadap anak yang belum tamyiz menjadi hak dari ibunya kecuali ibunya tiada, maka pemeliharaan anak dialihkan ke keluarga yang lain, jika ternyata pemegang hadlanah tidak dapat menjamin tumbuhkembang anak baik secara jasmani dan rohani, maka Pengadilan Agama atas permohonan keluarga yang punya hak dari anak dapat memindahkan hak hadlanah. Sesuai dengan syarat yang ditetapkan ulama fiqh tentang syarat agama Islam, maka jika memang

${ }^{23}$ Skripsi: M. Alfian Azizi. (2018) "Analisis Hukum Islam Terhadap Pertimbangan Hakim Tentang Hak Hadlanah Kepada Ibu Murtad di Pengadilan Agama Bangkalan" Fakultas Syariah dan Hukum Uin Sunan Ampel Surabaya, h. 66.

Humanistika: Vol.7 No.2 2021 


\section{Achmad Roni}

orangtua tidak beragama Islam keluarga lain dpat mengajukan hak hadlanah ke Pengadilan Agama. Dalam UU Perlindungan Anak orangtua berkewajiban membimbing dan merawat anak tanpa ada syarat agama apapun. Adapaun Jika terjadi perselisihan hak asuh terhadap anak, hakim di Pengadilan harus benar-benar memperhatikan dan mempertimbangkan apabila anak tersebut diasuh oleh ibunya atau oleh bapaknya dapat menjaminan kehidupan sosial dan kesejahteraan yang lebih baik dalam tumbuhkembang anak. Hal yang terpenting adalah kemampuan orangtua untuk mengasuh, merawat dan memelihara anak.

Humanistika: Vol.7 No.2 2021 


\section{Peranan Orangtua Murtad Terhadap Pemeliharaan Anak}

\section{DAFTAR PUSTAKA}

\section{Peraturan Perundang-undangan:}

Undang-Undang Nomor 15 Tahun 2019 tentang Perubahan atas Undang-Undang Nomor 12 Tahun 2011 tentang Pembentukan Peraturan Perundang-undangan.

Undang-Undang Nomor 35 tahun 2014 tentang Perubahan Atas Undang-Undang Nomor 23 tahun 2002 tentang Perlindungan Anak

Undang-Undang Nomor 1 Tahun 1964 tentang Perkawinan

Al-Imam Abu Zakaria Muhyiddin ibn Syarif al-Nawawi, alMajmu'Syarh al-Mazhab, Dar al-Fikr, terjemah-18

Jimly Asshiddiqie dan M. Ali Safa'at, Theory Hans Kelsen Tentang Hukum, Cetakan 1, Jakarta: Sekretariat Jenderal dan Kepaniteraan Mahkamah Konstitusi RI, 2006.

Zainuddin Ali, Hukum Islam Pengantar Ilmu Hukum Islam di Indonesia, Jakarta, Sinar Grafika,2006.

Zainuddin ibn Abd al-Aziz al-Malibẫri al-Fanẫni, Fath al-Mu'ĩn li alSyarh Qurrat al-'Aini, cet-1, Beirut, Libanon, 1418 H/ 1997

\section{Jurnal:}

Aldi Jaya Mandala Putra. (2017). “Tinjauan Yuridis Terhadap Pemeliharaan Anak Dibawah Umur Akibat Suatu Perceraian Berdasarkan Kompilasi Hukum Islam”. Journal Of Law. Vol. 1 No. 1.

Humanistika: Vol.7 No.2 2021 


\section{Achmad Roni}

Amrunsyah. (2017). “Tindak Pidana Perlindungan Anak (Perspektif Hukum Tentang Undang-Undang Perlindungan Anak)" $A L$ QADHA Jurnal Hukum Islam Dan Perundang-undangan, Vol. 4, No. 1.

Aris Bintania. (2011). "Hak Asuh (Hadlanah) Isteri Murtad Menurut Hukum Positif dan Hukum Islam." Toleransi, Vol 3 No.1, 2011.

Asril. (2015). "Eksistensi Kompilasi Hukum Islam Menurut UndangUndang Nomor 12 Tahun 2011 tentang Pembentukan Peraturan Perundang-Undangan”. Hukum Islam, Vol XV No. 1.

Bayu Dwi Anggono. (2018). "Tertib Jenis, Hierarki, dan Materi Muatan Peraturan Perundang-Undangan: Permasalahan dan Solusinya”. Masalah-Masalah Hukum, Jilid 47 No. 1.

Edy Gunawan. (2016). "Eksistensi Kompilasi Hukum Islam di Indonesia", Jurnal Ilmiah Al-Syir'ah, Vol VIII No. 1.

Islam, M. H. (2019). ISLAM AND CIVILIZATION (ANALYSIS STUDY ON THE HISTORY OF CIVILIZATION IN

ISLAM). Al-Insyiroh: Jurnal Studi Keislaman, 5(1), 22-39.

Islam, M. H. (2019, November). Model Pendekatan Halaqotul MuAllimin Al-Islamiyah dalam Membentuk Kepribadian Yang Rahmatan Lil Alamin Sebagai Identitas Kebangsaan di Pondok Pesantren Al-Mashduqiah. In Proceedings of Annual Conference for Muslim Scholars (Vol. 3, No. 1, pp. 491-503).

Islam, M. H. (2020). TOLERANCE LIMITATION IN FACING RELIGIOUS DIVERSITY BASED ON THE TEACHING

OF ISLAM. Nazhruna: Jurnal Pendidikan Islam, 3(1), 1-13.

Islam, M. H., \& Aziz, A. (2020). Transformation of Pesantren in Maintaining Good Character. HUMANISTIKA: Jurnal Keislaman, 6(1), 35-48.

Humanistika: Vol.7 No.2 2021 


\section{Peranan Orangtua Murtad Terhadap Pemeliharaan Anak}

Islam, M. H., \& Maskuri, M. (2020). Pembentukan Kepribadian

Multikultural melalui Pendidikan Diversitas. Pendidikan Multikultural, 4(1), 23-44.

Maswandi. (2017). "Hak Asuh Anak Yang Belum Dewasa Setelah Perceraian”, Jurnal Ilmu Pemerintaban dan Sosial Politik, Vol. 5, No. 1.

Ni'matul Huda. (2006). "Kedudukan Peraturan Daerah dalam Hierarki Peraturan Perundang-Undangan”. Ius Quia Iustum, Vol. 13 No. 1.

Rini Fitriani. (2016). "Peranan Penyelenggara Perlindungan Anak Dalam melindungi dan Memenuhi Hak-Hak Anak" Samudtra Keadilan, Vo. 11, No. 2.

Rohidin (2005), "Pemeliharaan Anak Dalam Perspektif Fiqh dan Hukum Positif" Jurnal Hukum, No. 29 Vol. 2.

Zaka Firma Aditya dan M. Reza Winata. (2018) "Rekonstruksi Hierarki Peraturan Perundang-Undangan Di Indonesia" Negara Hukum: Vol. 9, No. 1.

\section{Skripsi:}

M. Alfian Azizi, (2018), Analisis Hukum Islam Terhadap Pertimbangan Hakim Tentang Hak Hadlanah Kepada Ibu Murtad Di Pengadilan Agama Bangkalan, Fakultas Syariah dan Hukum Uin Sunan Ampel Surabaya

Humanistika: Vol.7 No.2 2021 